$34 \mathrm{~m}$

o. $-72-22$

op. 2

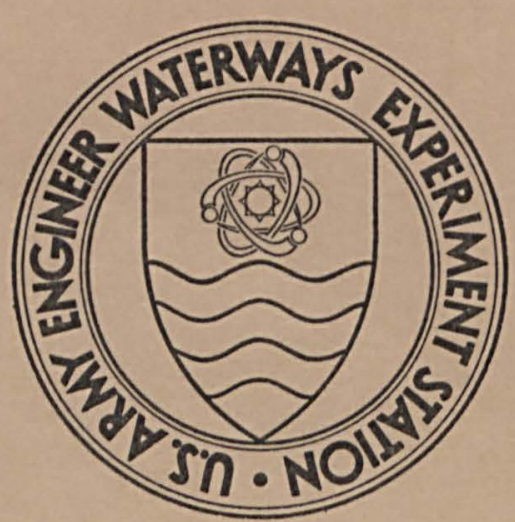

MISCELLANEOUS PAPER C-72-22

EXPANSIVE CEMENTS AND THEIR USE

by

G. C. Hoff
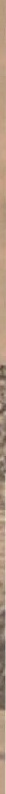

October 1972

Published by U. S. Army Engineer Waterways Experiment Station

Concrete Laboratory

Vicksburg, Mississippi 


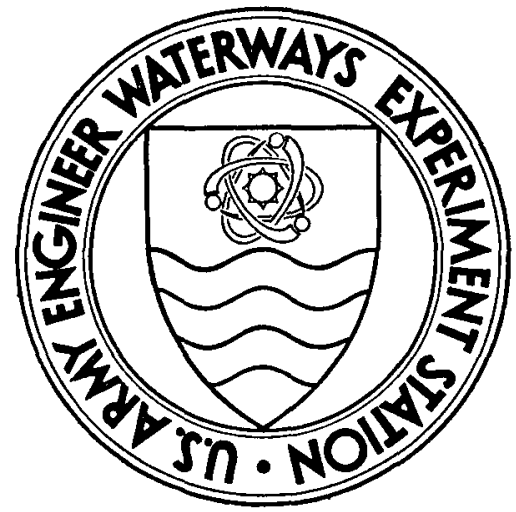

MISCELLANEOUS PAPER C-72-22

\section{EXPANSIVE CEMENTS AND THEIR USE \\ by}

G. C. Hoff

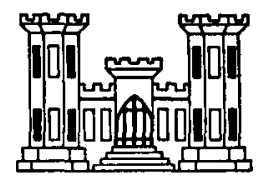

October 1972

Published by U. S. Army Engineer Waterways Experiment Station

Concrete Laboratory

Vicksburg, Mississippi

ARMY-MRC VICKSBURG. MISS 
DS:m

I) $C-7 a-12$

cop.?

FOREWORD

Th1s paper was prepared for presentation at the International Seminar on Concrete Technology held at Ciudad Universitaria, Monterrey, N. L., Mexico, in December 1972.

The cost of the reproduction of this state-of-knowledge report was defrayed by funding made avallable from the office, Chief of Research and Development, Army, for operation of the Concrete Technology Information Analysis Center (CTIAC). This is CTIAC Report No. 8. Th1s report was prepared by Mr. George C. Hoff, Chlef, Materials Properties Section of the Concrete Laboratory, U. S. Army Engineer WaterwaysExperiment Station (WES), under the general supervision of Messrs. Bryant Mather, Chief of the Concrete Laboratory, and James M. Polatty, Chief of the Engineering Mechanics Branch, Concrete Laboratory.

The Director of WES during the preparation and publication of this paper was COL Ernest D. Peixotto, CE. Technical Director was Mr. F. R. Brown. 
FOREWORD. . . . . . . . . . . . . . . 1111

ABSTRACT. . ............................. vi1

INTRODUCTION. . . . . . . . . . . . . . . . 1

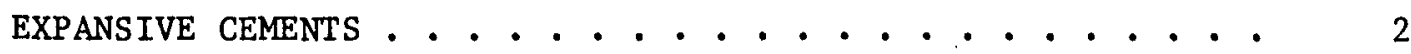

Why Do Expansive Cements Expand? . . . . . . . . . . 2

How Do Expansive Cements Work? . . . . . . . . . . 3

Expansion Determinations........... 4

FACTORS INFLUENCING EXPANSION . . . . . . . . . 6

Cement Content. . . . . . . . . . . . 7

Aggregate Content. . . . . . . . . . . . 7

Mixing Times ................ 8

Curing. . . . . . . . . . . . . . . 8

Temperature. . . . . . . . . . . . . 9

Restraint. . . . . . . . . . . . . 9

PROPERTIES OF SHRINKAGE-COMPENSATING CONCRETES. . . . . . 10

Fresh Concrete................ 10

Hardened Concrete. . . . . . . . . . . . 10

MIXTURE DESIGN. . . . . . . . . . . . . . 13

Water Requirements . . . . . . . . . . 13

Aggregates ................ . . . 14

Cement Factor. . . . . . . . . . . . . 14

Admixtures .................. . . 15

PlACING, FINISHING, AND CURING. . . . . . . . . . 16

Placing. . . . . . . . . . . . . . 16

Finfshing. . . . . . . . . . . . . . 18

Curing ...................... 19

STRUCTURAL DESIGN CONSIDERATIONS. . . . . . . . . . 20

APPLICATIONS. . . . . . . . . . . . . . . . 24

SUMMARY. . . . . . . . . . . . . . . . 25

REFERENCES . . . . . . . . . . . . . 26

FIGURES $1-13$ 


\section{ABSTRACT}

The primary purpose of shrinkage-compensating expansive cement concrete is to minimize cracking in concrete pavements and structures caused by drying shrinkage. The paper reviews the various types of expansive cements and their properties. The expansive mechanism and factors affecting it are also reviewed. The physical properties of shrinkage-compensating concrete along with practical considerations such as mixing, placing, finishing, and curing are discussed. Structural design criteria for these concretes are reviewed. Applications involving the use of shrinkage-compensating concretes are suggested.

Expansive cement types $K, M$, and $S$ are available in both shrinkagecompensating and self-stressing grades. The amount of expansive potential a cement has determines its grading and is controlled by the ingredients and formulation of the cement. The effective utilization of this potential is controlled by the cement supplier or user or both. Such features as cement content, aggregate type, mixing times, curing, temperature, and restraint can affect expansion.

An expansive cement is effective only when the hardened paste made with the cement is sufficiently restrained from expanding so that compressive stresses are developed in the material. Seven-day restrained prism expansions for concrete made with shrinkage-compensating cement are usually within the 1 imits of 0.03 to 0.10 percent. This corresponds to compressive prestress developments in the concrete in the range of 25 to 100 psi ( 0.17 to 0.69 megapascals). 
expanding cements could also be used to develop a compressive prestress in concrete and thus aid in reducing shrinkage cracking was first postulated by Henri Lossier in the mid 1930's. Since Lossier's early expansive cement work, considerable development of expanding cements has taken place in the USA, Russia, and Japan. For further historical background and details, the interested reader is referred to References 1 to 5 and their bibliographies. These references and Reference 6 contain most of the information available through 1972 on expansive cements and expansive cement concretes and provided much of the substance of this paper.

\section{EXPANSIVE CEMENTS}

An expansive cement is a cement which, when mixed with water, forms a paste, that during setting and after hardening, increases significantly in volume. From the development of expanding cements came types $K, M$, and $S$ cements. These designations were assigned by the American Concrete Institute. Type $K$ cement was developed by Alexander Klein at the Unfversity of California. Type M cement was developed by V. V. Mikhailov in the Soviet Union. The Portland Cement Assuciation developed type S cement. The USA producers of type M cement refer to their product as type MX cement as its formulation is different from Mikhailov's. The constituents of the three types of expansive cement are summarized in Fig. 1 . Why do expansive cements expand?

The mechanism of expansion of expansive cements is not fully understood but it is generally agreed that expansions are associated with the 
formation of ettringite $\left(3 \mathrm{CaO} \cdot \mathrm{Al}_{2} \mathrm{O}_{3} \cdot 3 \mathrm{CaSO}_{4} \cdot 32 \mathrm{H}_{2} \mathrm{O}\right)$. As seen in $\mathrm{Fig} .1$, all three expansive cements have at least two things in common - aluminates and calclum sulfate. The reactive aluminate needed for the formation of ettringite $\left(\mathrm{C}_{3} \mathrm{~A} \cdot 3 \mathrm{CS} \cdot \mathrm{H}_{32}\right)$ * in the type $\mathrm{K}$ cement is an anhydrous calclum aluminosulfate $\left(\mathrm{C}_{4} \mathrm{~A}_{3} \bar{S}\right)$, in the type $M$ cement a calcium aluminate (CA and $\left.\mathrm{C}_{12} \mathrm{~A}_{7}\right)$, and in the type $\mathrm{S}$ cement the tricalcium aluminate $\left(\mathrm{C}_{3} \mathrm{~A}\right)$. The type of aluminate and the amounts of aluminate and calcium sulfate used control both the rate and total amount of ettringite produced, hence, they also control the expansive potential of the cement. How do expansive cements work?

Expansive cements, when properly used in concrete, cause the hardened concrete to increase in volume. If the concrete is restrained from expanding, compressive stresses can develop in the concrete. Restraint can be either internal or external. Both the compressive prestress resulting from the restrained expansion and the tensile strength of the concrete must then be overcome by the tensile stress associated with drying or other phenomena before a crack can form.

Depending on the magnitude of restrained expansion, or the level of prestress in the concrete, expansive cement concretes are classified as either shrinkage-compensating or self-stressing. Shrinkage-compensating concrete is designed to induce a large enough level of restrained expansion during curing to offset the subsequent contraction due to drying shrinkage. The level of compressive prestress developed is generally in the range of 25 to $100 \mathrm{psi}(0.17$ to 0.69 megapascals). Self-stressing concrete is designed to induce large enough levels of compressive stress $\overline{\star C}=\mathrm{CaO}, \mathrm{A}=\mathrm{Al}_{2} \mathrm{O}_{3}$, and $\mathrm{S}=\mathrm{SO}_{3}$ 
so that even after stress loss due to drying shrinkage the concrete will remain under substantial compression. The practical range of compressive prestress levels in self-stressing concrete is between 150 to 500 psi ( 1.03 to 3.45 megapascals) although higher levels have been achieved in the laboratory.

Shrinkage-compensating concrete will be the only type of expansive cement concrete considered in the remainder of this paper. Many of the considerations discussed for shrinkage-compensating concrete are also applicable for self-stressing concrete. Readers interested in self-stressing concretes can find information on these concretes in References 1,3 , and 5 .

Expansion determinations

The methods for testing for expansion of expansive cement mortar or concrete are varied. The most common procedure for determining expansion characteristics is the measurement of length changes of restrained prisms. The prism for a mortar is usually 2 by 2 by 10 in. ( 50 by 50 by $250 \mathrm{~mm}$ ) with a 10-in. (250-mm) gage length. The prism is restrained by an axially located 1/4-in. (6.35-mm) -20 threaded rod which connects two $3 / 8-\mathrm{in} .(9.52-\mathrm{mm})$ end plates. For expansive cement concretes the prism is usually 3 by 3 by 10 in. ( 75 by 75 by $250 \mathrm{~mm}$ ) with a $10-i n .(250-\mathrm{mm})$ gage length. The restraining cage is similar to that of the mortar prism with the exception that a 3/16-in. (4.83-mm) -24 threaded rod is used in the larger prism. 
A restrained expansion bar showing the restraining cage is shown in Fig. 2. The restraining cage is placed in steel mold for casting. The molds are usually removed at ages of 6 or 7 hours with the initial length measurement being made at that time. The prisms are generally water cured for at least 7 days. The 7-day expansion of a shrinkage compensating concrete, as measured on the prism, is frequently specified to be within the limits of 0.03 to 0.10 percent. If information is desired on the loss of expansion due to drying shrinkage, the prisms can be transferred to air curing in a low humidity room and appropriate length measurements taken.

A field practice for qualitatively determining whether the concrete is in fact expanding is to glue gage buttons onto the quality control compressive strength specimens immediately after their casting molds are removed and then with appropriate measuring devices, determine whether the button spacing is increasing with time. The nolds are usually removed from the specimens within 24 hours after casting.

A committee of the American Society for Testing and Materials is now preparing a specification for expensive cements which includes a standard method of test for measuring expansion of expansive cement mortars. The Committee on Expansive Cement Concretes of the American Concrete Institute is presently preparing a Recommended Practice for the Use of Shrinkage-Compensating Concretes which includes a standard method of test for expansion of expansive cement concretes. Both of these methods use the restrained prism as the test specimen. 


\section{FACTORS INFLUENCING EXPANSION}

Some of the factors which influence the rate and amount of expansion are controlled by the producer of the cement and some by the supplier or user of the expansive cement concrete.

Expansive cements are essentially portland cements containing from 10 to 30 percent expansive constituents. The producer controls the expansion characteristics of the cement by selecting the appropriate proportions of the expansive constituents so that enough $\mathrm{CaO}, \mathrm{SO}_{3}$, and $\mathrm{Al}_{2} \mathrm{O}_{3}$ are available for the desired amount of ettringite formation. Ettringite starts to form as soon as water is added to the cement during mixing and continues to form during the subsequent curing period until the $\mathrm{SO}_{3}$ or $\mathrm{Al}_{2} \mathrm{O}_{3}$ is exhausted.

The rate of expansion is also considered by the producer in the selection of the composition of the expansive cement. It is essential that the major part of ettringite formation takes place after the cement has gained some strength, otherwise the expansion would only deform the still plastic concrete without developing the desired compressive stress in the restrained concrete. In addition, most of the expansion should teminate within the relatively short period of about 4 to 7 days, since in practice the moist curing periods are usually short, and water is required for the formation of ettringite.

The fineness of the cement also has a significant influence on the rate and amount of expansion. An example of the effect of fineness on expansion is shown in Fig. 3 for self-stressed concretes made with a type $\mathrm{K}$ cement ground to four different degrees of fineness. Shown in 
this figure is the expansion of the concrete at the end of the moist curing period and the residual expansion after subsequent shrinkage during storage in air at 50 percent relative humidity.

The supplier or user of an expansive cement concrete can also control to some degree its expansion characteristics. Some of the important factors influencing expansion that need to be considered include the cement content, type of aggregate, mixing time, curing, temperature, and degree of restraint.

\section{Cement content}

The richer an expansive cement concrete mixture, the larger will be its expansion. The effect of cement content on expansion is illustrated by Fig. 4 for expansive cement concrete made with type $\mathrm{K}$ cement. By increasing the cement content from 510 to 790 1b per cu yd (303 to 469 kilograms per $\mathrm{cu} \mathrm{m}$ ), the expansion after 7 days of curing more than doubled (from 0.07 to 0.20 percent)。

\section{Aggregate type}

In expansive cement concretes there are two properties of aggregate that have an important effect on its expansion characteristics. They are the compressibility of the aggregate which will influence the magnitude of expansion, and the effect of the aggregate on the shrinkage characteristics of the concrete which will influence the magnitude of stress loss due to drying shrinkage. The data of Fig. 5 are an example of the effect aggregate type has on the expansion and subsequent shrinkage of a shrinkage-compensating concrete. Each of the concretes were 
proportioned to contain the same volume of aggregate and the same quality of expansive cement paste. The maximum expansion for the four aggregate types ranged from about 0.05 to 0.08 percent. There was also a difference in the shrinkage characteristics of the four concretes each made with a different aggregate type. The expansion characteristics appear to be almost directly related to their modulus of elasticity. The lightweight aggregate concrete which had an elastic modulus only about half of the modulus of the crushed granite or river gravel concretes also had an expansion only half as great. Tests with other lightweight aggregates of higher elastic modulus have shown greater expansions. The high absorption of 1 ightweight aggregates is an advantage for expansive cement concretes since the water held in the pores of the aggregate provides internal curing water needed for the expansive reaction of the cement.

\section{Mixing times}

Increasing the time of mixing decreases the expansion of all expansive cements. Mixing accelerates formation of the ettringite and thereby depletes the availability of this hydrate for later expansion.

\section{Curing}

The importance of adequate curing for expansive cement concretes cannot be over emphasized. Two hydration reactions require water: the formation of the strength-giving calcium silicate hydrates, and the formation of the expansion-causing compound ettringite. Maximum expansion can be obtained when the concrete is water cured. Figure 6 shows the 
effect of different curing conditions on the expansion of concretes made with type $\mathrm{S}$ cement. There is only a small difference in the expansion of concrete specimens stored in water as compared with those stored in a 100 percent relative humidity curing room. However, sealing the concrete specimens in a polyethylene bag, simulating a membrane curing, resulted in an expansion of only one-half that obtained with moist curing. Temperature

Concrete temperature during mixing and subsequent curing will influence the rate and magnitude of expansion because of its effect on the rate of ettringite formation. It would be expected that a high temperature, which increases the expansive reaction, would result in a larger expansion. The higher temperatures also accelerate the rate of strength gain. The higher strengths then tend to resist expansions and reductions in the ultimate expansion may occur. Figure 7 shows this type of behavior. The $100 \mathrm{~F}$ (38 c) curing produced a greater initial rate of expansion than the $70 \mathrm{~F}(21 \mathrm{C})$ curing but resulted in a reduction of 0.04 percent in the ultimate expansion at 28 days age. The low restrained expansion of the $45 \mathrm{~F}$ (7 C) cured concrete is not only due to a slow rate of ettringite formation but also to the slow rate of strength gain permitting greater creep deformations.

\section{Restraint}

To develop the required level of compressive stress in the concrete, and thus be effective as shrinkage-compensating or as self-stressing, the concrete must be restrained with steel reinforcement. To fully 
utilize this steel reinforcement the concrete should be permitted to expand in order to develop tension in the steel and compression in the concrete. Restraint provided by subgrade friction or by adjacent structures will also develop compressive stress in a shrinkage-compensating concrete and minimize the formation of cracks due to drying shrinkage.

The amount of reinforcement, or degree of restraint, affects the magnitude of expansion and the stress developed. For a given concrete mix an increase in restraint will reduce expansion but increase the compressive stress in the concrete.

\section{PROPERTIES OF SHRINKAGE-COMPENSATING CONCRETES}

The properties of shrinkage-compensating concretes are in most respects similar to those of corresponding portland cement concretes made with type I and II cements.

\section{Eresh concrete}

Shrinkage-compensating concretes have about the same workability as portland cement concretes at equal slump. Compared to portland cement concretes, they generally exhibit a greater slump loss with time and have a tendency to reach initial and final set more rapidly. They exhibit much less bleeding and in some cases do not bleerl at all. Both the slump loss and reduced bleeding are related to the high water demand of the ettringite formation.

\section{Hardened concrete}

The physical properties of shrinkage-compensating concretes, including strength, modulus of elasticity, shrinkage and durability, 
are comparable to those of corresponding portland cement concretes. The many factors which influence the various properties of portland cement concretes, such as water-cement ratio, cement content, curing period, and others, have similar influence on the properties of shrinkagecompensating concretes.

The strength development of shrinkage-compensating concretes is similar to that of comparable type I portland cement concretes. This is true for compressive, tensile, as well as flexural strength. Typical compressive strength data for type $\mathrm{K}$ shrinkage-compensating concretes up to age 60 days are shown in Fig. 8. In general, expansive cement concretes produce somewhat greater compressive strengths than comparably designed type I cement concretes. This can also be seen in Fig. 9 which shows the effects of increasing expansive cement content on compressive strength. Increasing the expansive cement content also increases expansions. A point can be reached where the amount of expansion occurring can have a disruptive effect on standard strength test specimens and reductions in strength will occur.

The effect of water-cement ratio on the compressive strength of type $\mathrm{K}$ cement concretes is shown in Fig. 10. At normal water-cement. ratios and cement contents, the compressive strengths of the type $K$ cement concrete are frequently higher than those of a corresponding type $I$ cement concrete. There is no good explanation for this behavior.

In general, the modulus of elasticity of shrinkage compensating concretes is comparable to that of portland cement concretes. The modulus 
of elasticity is influenced by the magnitude of expansion with increases in expansion reducing the modulus.

The drying shrinkage characteristics of shrinkage-compensating concretes are similar to those of type I portland cement concretes. The drying shrinkage of these concretes is affected by the same factors which affect the drying shrinkage of normal portland cement concrete, that is, curing, water content of the concrete mixture, and aggregate type and concentration. The influence of water-cement ratio on expansion during moist curing and drying is shown in Fig. 11. Note that the higher water-cement ratio concretes experienced a net contraction at later ages and thus developed some small tensile stresses which could lead to cracking. When properly designed, expansive-cement concretes should still remain under a slight compression for periods longer than 1 year (Fig. 12).

Limited data available on the creep characteristics of shrinkagecompensating concretes indicate that their creep coefficients are within the same range as those of corresponding portland cement concretes. Resistance to freezing and thawing and de-icer scaling at comparable air contents are about the same for the shrinkage-compensated and the portland cement concretes. The type of expansive cement used appears to have a significant influence on the sulfate resistance of the concrete. If sulfate attack is a problem, the expansive cement being considered for use should be evaluated for its sulfate resistance prior to its actual use on the job. 


\section{MIXTURE DESIGN}

In general, shrinkage-compensating concretes can be proportioned in the same manner as structural concrete mixtures using type $I$ and type II portland cements. With the exception of water requirement proportioning procedures recommended in ACI-211.1-70 for normal weight concretes and ACI-211.2-69 for lightweight concretes can be followed.

\section{Water requirements}

The chemical reactions which result in the formation of ettringite, and cause expansion, increase the water requirement of expansive cements as compared to type I or type II portland cement. For types $\mathrm{K}$ and $\mathrm{S}$ cements, an increase in water-cement ratio of about $0.05-0.10$ over that of a similar mixture containing type I or II cement may be required. The producer of type $M$ cement claims little or no increase is necessary for his cement. This difference can be attributed to variations in the hydration rates between the three cement types. As many external factors can affect the hydration rate, it is best to evaluate the mixture to be used under anticipated field conditions.

Special consideration must be given the increased initial water requirements when dealing with ready-mix concrete due to variations in delivery time or concrete temperatures or both. When using types $K$ and S cements, significant loss in slump or workability can occur with increased delivery times after batching or waming temperatures. This slump loss is usually greater for type $K$ than for type $S$. Sufficient slump must be provided at the batch plant to ensure that the desired slump is obtained at the jobsite. It should be noted that, within reasonable limits, increases in additional initial mixing water, when 
required to offset slump 10ss, are used in the formation of ettringite and hence has little effect on concrete properties because the "water of convenience" in the concrete is not increased. In general, shrinkage compensating concrete develops compressive strength and other engineering properties comparable to type I portland cement concrete at the same cement content and using the same aggregates when placed at the same slump although the slump may have been greater when it left the batching plant. Slumps at placing of 4 to $6 \mathrm{in.}$ (10 to $15 \mathrm{~mm}$ ) for normal weight concrete and 3 to $4 \mathrm{in.}(7$ to $10 \mathrm{~mm}$ ) for lightweight concrete are common.

\section{Aggregates}

Aggregate selection should follow standard procedures used with normal portland cement concrete as regards quality and proportions of fine and coarse aggregate. Reliable information as to the proportions of lightweight fine and coarse aggregates and their total uncombined volumes to produce $1 \mathrm{cu}$ yd $(0.765 \mathrm{cu} \mathrm{m})$ of concrete can usially be obtained from the lightweight aggregate producer. When this information is not available, section 3.2 of ACI 211.2-69 is a recommended guide.

\section{Cement factor}

Shrinkage-compensating cement concretes made with the same cement factor, aggregates, and consistency as concretes made with type I cement will have comparable compressive strengths. When determining the necessary proportions for the mixture to satisfy a strength or workability requirement, it must be remembered that variations in the cement content and water-cement ratio also affect expansion. Expansions increase with 
Increased cement factors and decrease when the cement factor is lowered. Must producers of expansive cement recommend a minimum cement factor of 510 lb per cu yd (302.6 kg per cu m) with approximately 0.15 percent reinforcement in order to assure adequate restrained expansion. With increased cement factors, additional reinforcement would be needed to maintain acceptable levels of expansion.

\section{Admixtures}

Air-entraining admixtures, which comply with ASTM C 260, may be used effectively in shrinkage-compensating cement concrete. Generally, the same amount of a given admixture will produce the same percentage of air in concretes made with either shrinkage-compensating, type I, or type II cement, all other conditions being the same.

Water-reducing and water-reducing-retarding admixtures of all types, which comply with ASTM C 494, have been used in shrinkage-compensating cement concrete. Some of these admixtures have not been compatible with certain shrinkage-compensating cements, however. Certain type $A$ and type $D$ admixtures when used with some expansive cements have resulted in excessive slump loss or a substantial loss of expansion or both. If definite knowledge of satisfactory performance of a particular admixture in a particular expansive cement is not available, evaluations of their compatibility should be made prior to use on the job. Under noderate temperature conditions, acceptable admixtures can generally be used in shrinkage-compensating cement concretes at the same dosage as in concretes made with type I or II cement. At concrete temperatures of $86 \mathrm{~F}$ 
(30 C) larger than normal dosages have been successfully used to retard the set.

Accelerators, notably calcium chloride, should be used with caution. There has been no wholly successful accelerator used that has given consistently satisfactory results. The use of accelerators should be discussed with the cement producer prior to any attempt to use it with his product.

\section{PLACING, FINISHING, AND CURING}

\section{Placing}

The characteristics of shrinkage-compensating cement concrete in the unhardened state are sufficiently similar to concretes made with type I and II cement so that no special placement techniques are required. Recommendations set forth in ACI 614-59 "Recommended Practice for Measuring, Mixing and Placing Concrete, Chapter V, Placing," should be followed. Successful placements have accomplished using most placing techniques employed with conventional concretes. In all respects, the placing of type $M$ concretes can be considered identical to that of concretes made with type I or type II cement. It is generally felt that type $\mathrm{K}$ and $\mathrm{S}$ shrinkage-compensating concretes have sonewhat more cohesiveness or "fat" than standard concrete and thus less tendency to segregate. It is this feature which makes these types more adaptable to pumping and a large percentage of their use has been placed in that manner. The problem of slump loss resulting from excessive delivery times or waming temperatures also affects placement and was discussed previously. 
Extensive mixing times, whether in transit trucks or central batch plants, should always be avoided as they also contribute to substantial slump loss and also reductions in expansion. The mixing time is more critical at high temperatures and should be 1 imited to 45 minutes at $85 \mathrm{~F}(30 \mathrm{C})$. Longer mixing times can be tolerated at lower temperatures. When placing shrinkage compensating cement concretes at temperature extremes the recommendations of ACI 605-59 "Recommended Practice for Hot Weather Concreting" and ACI 306-66 "Recommended Practice for Cold Weather Concreting" for conventional concrete also apply and should be followed.

Where the unhardened expansive cement concrete will be in contact with an absorbtive material such as soil or ireviously placed dry concrete, the base or subgrade should be wet thoroughly. light sprinkling is not sufficient. A thorough soaking the evening before placing followed with sprinkling just prior to placing would be more desirable. Vapor barriers should be used with caution because of the limited bleeding of shrinkage-compensating cements. Experience with type $K$ and $s$ cement concretes placed under hot and dry conditions has shown that with some vapor barriers plastic cracking is much more prevalent along with finishing difficulties because of uneven drying. A minimum of 3 in. of sand, thoroughly prewetted, placed between the vapor barrier and the concrete has consistently produced good results, however.

Consolidation by vibration or other appropriate methods should be used to ensure uniform bond with the steel. This bond is necessary in order to develop the proper restraint in the concrete. Extra care must 
be exercised to maintain all the reinforcement in its proper position particularly in thin slabs or pavements.

Although the majority of the expansion takes place while the concrete is still in the form, it has not been found necessary to provide any additional strenghening of the formwork.

\section{Finishing}

The cohesiveness inherent with types $K$ and $S$ expansive cements is claimed to provide superior finishing qualities. Expansive cements typically make their set faster than type I and II portland cements and the finishing process can then start somewhat sooner. The expansive cements also bleed less than portland cements and this must also be considered when determining the proper time to start the finishing operation. The disappearance or absence of bleed water may cause finishers to start too soon. The combination of these features may require greater finishing manpower for a shorter period of time than would be typical for normal concrete finishing operations.

The lack of bleed water in some expansive cements can, in a dry and windy condition, cause plastic shrinkage cracks to develop in the concrete. The normal accepted procedures such as wind screens, fog sprays, etc., should be used when such situations occur. Generally, satisfactory results are obtained when the recommendations of ACI 614-59 "Recommended Practice for Measuring, Mixing and Placing Concrete," Section VI, paragraph 7, are followed in performing the $f$ inishing operation. 


\section{Curing}

To assure the adequate development of expansive potential and strength of shrinkage-compensating cement concrete, water curing for a minimum of 3 days is an absolute necessity. The initial curing period should be followed by an additional period of water curing or an appropriate method of curing which will retain moisture in the concrete. Numerous successful applications of a curing membrane properly applied immediately after the finishing operation have been achieved. Care must be taken to assure that all available moisture is retained in the concrete to support the expansion. Curing compounds when used should comply with ASTM C 309. Curing with plastic sheeting has had limited success.

As with conventional concrete, expansive cement concrete must be protected in cold weather during the critical enrly ages to prevent it from freezing. Nomal cold weather concrete practices (ACI 308-66) for protection should be followed.

Curing temperatures will affect the amcunt of expansion obtained. How it affects it is presently a source of controveray. It is generally agreed that greater expansions are obtained at moderate temperatures. A minimum curing temperature of $50 \mathrm{~F}(10 \mathrm{C})$ is recommended in order to achieve the desired expansions. Successful placements with regard to expansion, have been made utilizing retarders when the temperatures were between 90 and $100 \mathrm{~F}(32$ and $38 \mathrm{c})$. If possible curing temperatures should be maintained between 50 and $75 \mathrm{~F}$ (10 and $24 \mathrm{C}$ ) for the first 7 days. When it is known that this temperature range will be exceeded, 
consultation with the cement supplier regarding his past experience with the cement may be necessary so that mixture adjustments can be made.

\section{STRUCTURAL DESIGN CONSIDERATIONS}

The purpose of using shrinkage-compensating cement in lieu of normal portland cement in concrete is to prevent or minimize cracks caused by drying shrinkage. The structural design parameters used in the design of portland cement concrete elements are therefore the same as those that would be required in the design of concrete elements containing shrinkage-compensating cement. Generally, any prestress which occurs in the reinforcing steel during expansion can be ignored as its presence tends to make a design more conservative from a safety standpoint.

The benefits derived from using shrinkage-compensating cement are lost if adequate restraint is not provided to the expanding element. While restraint can be provided by reinforcement, adjacent structures, subgrade friction, mass, or forms, the effects of the last three are largely indeteminate. Adjoining structure restraint should only be considered if it is known that the structure will actually provida the restraint required. The most reliable and controllable restraint is provided by conventional reinforcing stee1. As the amount or percentage of steel in a member increases, the compressive stress developed in the concrete by given expansive cement also increases. The magnitude of compressive stress developed in the concrete can be computed as follows:

$$
f_{c}=\epsilon_{c} \cdot p \cdot E_{s}
$$


where

$$
\begin{aligned}
\epsilon_{c} & =\text { strain of concrete } \\
p & =\text { steel ratio } A_{s} / A_{C} \\
E_{S} & =\text { modulus of elasticity of steel } \\
A_{S} & =\text { area of steel } \\
A_{C} & =\text { area of concrete }
\end{aligned}
$$

This computation is applicable both while the concrete is expanding and also while it is shrinking due to drying shrinkage. Figure 13 shows the relationship between expansion and concrete stress for various amounts of reinforcement where $E=29 \times 10^{6}$ psi ( $2 \times 10^{5}$ megapascals). It has been reported that steel percentages of approximately 1-2 percent result in the maximum amounts of stress that can be developed. In structural members the nomal reinforcement as calculated by $\mathrm{ACI}-318-71$, 'Building Code Requirements for Reinforced Concrete,"will provide satisfactory restraint for shrinkage compensation. Nonload bearing members should have a minimum of 0.15 percent steel in each direction to ensure development of the desired compressive stresses.

Deflection analyses to satisfy load performance criteria can be made in the same manner as with portland cement concrete.

With the exception of drying shrinkage, all the mechanisms which can cause cracking in portland cement concrete will also cause cracking in shrinkage-compensating concrete. Standard methods for control and prevention of these cracks must still be utilized in the design of structures made with shrinkage-compensating concrete.

Slabs on grade should also contain a minimum of 0.15 percent reinforcement. The position of the reinforcement in the slab, as well as all other elements made with shrinkage-compensating concrete, is very 
important. Warping, due to nonuniform expansions, is a possibility when the steel reinforcement is concentrated in one portion of the section or where wire mesh reinforcement is misplaced. In general, deformed reinforcing bars are preferred over wire mesh as their locations are usually more stable during concrete placing. Many successful jobs using wire mesh have been completed, however. Because drying occurs on the top surface of slabs on grade and not on the bottom, the steel should be located in the upper half of the slab. When wire mesh is used, the. mesh should be "walked in" from the top of the slab, or sandwiched between two layers of unhardened concrete, or placed on supports at the proper height. Hooking the mesh from the slab bottom through the unhardened concrete is not recommended. With the steel located near the center of the slab and with excellent subgrade friction, the possibility exists of slight arching in the slab after expansion. Subsequent drying from the top surface should straighten out the slab. Using shrinkage-compensating concrete, slab placement areas can be increased to $15,000-20,000 \mathrm{sq}$ ft (1400-1860 sq meters) from the checkerboard patterns of approximately $2500 \mathrm{sq}$ ft (230 sil meters) normally used. This results in a substantial reduction in the number of coustruction joints. The length to width ratio of the placement areas should be maintained as nearly as possible to $1: 1$ in order to avoid nonuniform expansion and drying shrinkage. For keyed construction joints, the reinforcement should not pass through the joint. The same is true for doweled construction joints with the dowels also being greased or wrapped to prevent bond. To minimize joint opening slabs should not be placed on vapor barriers where it can be avoided. 
Expansion joints for the control of thermal movements are just as necessary with shrinkage-compensating concrete as with normal concrete. Reinforcement should be stopped at the joint to permit movement. When minimum steel is used at expansion joints or with the use of premolded bond breakers, the reinforcement should be doubled for a 2- to 3-ft (0.6 to 0.9 meters) distance to compensate for lack of external restraint in the area. When mesh is used, another mesh layer for a distance of one roll width should perform the same function. A maximum spacing of $100 \mathrm{ft}$ ( 30.5 meter) for contraction joints is commonly used. Joint spacings of $150 \mathrm{ft}(45.7$ meters) in exposed areas, and $200 \mathrm{ft}$ (61 meters) in protected areas have been used successfully, however.

If necessary footings, pits, walls, and drains should be protected by isolation joints to prevent damage during the early expansion stage of the concrete.

Column box-outs may be reduced or eliminated. Bond breakers wrapped around the column or cardboard forms brought to floor level have been satisfactory in permitting vertical movement. At the same time the mesh should be increased in the column flange area where high stresses normally develop.

Connections between prefabricated members or cast-in-place members made with shrinkage-compensating concrete have been designed in the same manner as for portland cement concrete with no problems occurring. Designs should be checked to ensure that the expansive force does not produce any undesirable movements. 


\section{APPLICATIONS}

Shrinkage-compensating concretes have been used in most situations where portland cement concretes have been used. A major exception is in ocean construction. With proper care, they can also be used in that capacity. An estimated $2,000,000$ barrels ( 380,000 tons) of expansive cement were used in 1972. Projections are for more than twice that amount in 1973.

The first shrinkage-compensating concrete placed in the United States was in a folded plate roof of the Midvalley Savings and Loan Association in Yuba, California, in 1963. In the 10 years since that first job, it has repeatedly been used in parking facilities, tilt-up construction, pavements, water and waste-water works, swimming pools, sports arenas, tennis courts, transportation centers, waruhouses, architectural applications, and precast operations. Shrinkage-compensating cements have also been used in grouting operations. The elimination or minimizing of cracking makes it ideally suited for applications where water leakage might be a problem such as parking facilities, water and waste-water plants, and swimming pools. The reduction or elimination of construction joints is of great benefit in pavements, floor slabs in sports arenas and warehouses, and in tennis courts. The ability to prestress the reinforcement makes it very useful in precast operations such as concrete pipes, building elements and modules, and tilt-up construction. The volume stability of the concrete, that is attaining the same size as-cast after shrinkage has occurred, plus its reduced cracking, are useful in many architectural applications. Nonshrink grouts 
can be used in many situations. The possibilities for advantageous utilization of the expansive behavior of shrinkage-compensating cements are many and are $1 \mathrm{imited}$ only by the innovativeness and ingenuity of the architect and engineer who build with concrete.

\section{SUMMARY}

Expansive cement concrete can be used to advantage in almost all types of structures. The same good practices used to produce quality portland cement concrete are essential to the successful production and use of expansive cement concrete. The use of expansive cement concrete will not compensate for poor design or poor construction procedures. Proper restraint and adequate curing are the keys to effectively using expansive cements in concrete. 


\section{REFERENCES}

1. Report of ACI Committee 223, "Expansive Cement Concrete - Present State of Knowledge," Journal ACI, Proc, V 67, No. 8, pp 563-610, August 1970.

2. Price, R. E., "Expansive Cements - Applications and Field Problems," Proc of Conference on New Materials in Concrete Construction, University of Illinois at Chicago Circle, December 1971.

3. Conference on Expansive Cement Concrete, Proceedings, University of California, Berkeley, June 1972 (16 papers).

4. Hoff, G. C., "Investigation of the Behavior of Large Sections of Expanșive Concrete - Jonesville Lock," U.S. Amy Engineer Waterways Experiment Station, Concrete Laboratory, Vicksburg, Mississippi, June 1972 .

5. ACI Committee 223, Proceedings of a Symposium on Expansive Cements and Expansive Cement Concretes, American Concrete Institute, Detroit, Michigan, November 1972.

6. TXI 4C ChemComp Technical Manual, Texas Industries, Inc, Arlington, Texas, 1972. 


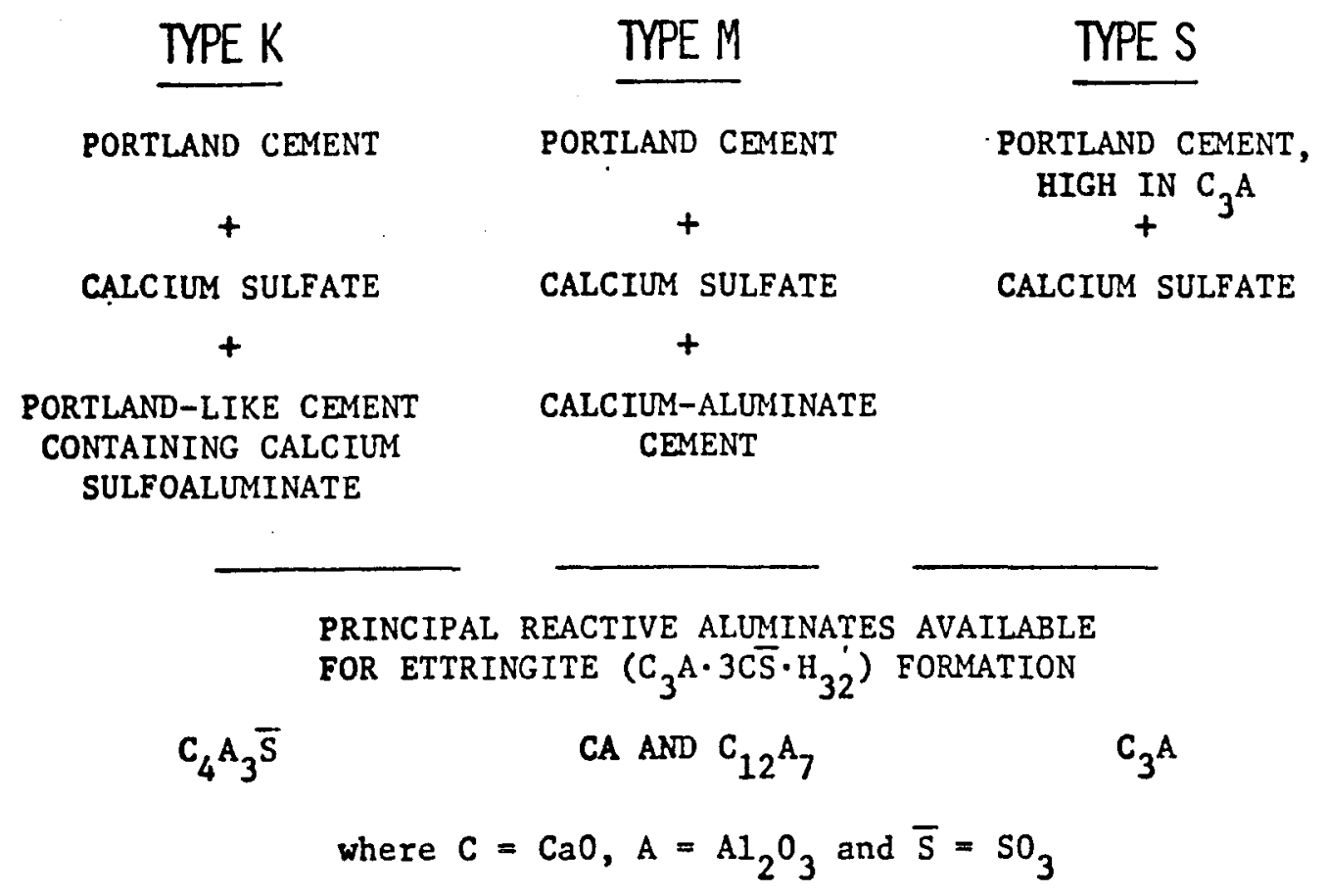

EIGURE 1. TYPES OF EXPANSIVE CEMENTS AND THEIR- CONSTITUENTS

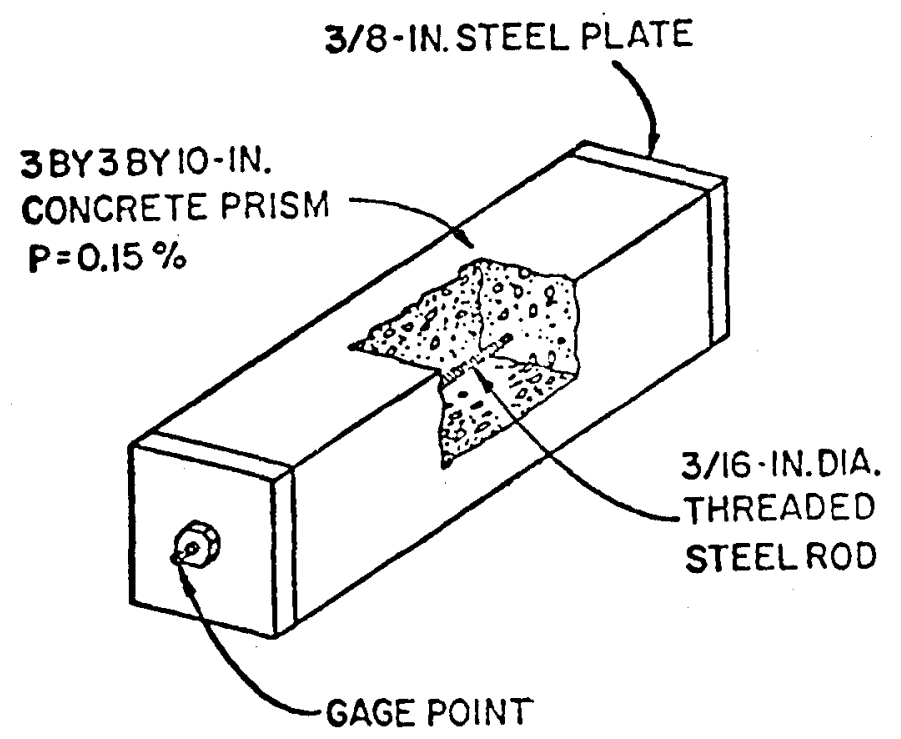

FIGURE 2. RESTRAINED CONCRETE PRISM USED TO MEASURE LENGTH CHANGES OF SHRINKAGE-COMPENSATING CONCRETE 


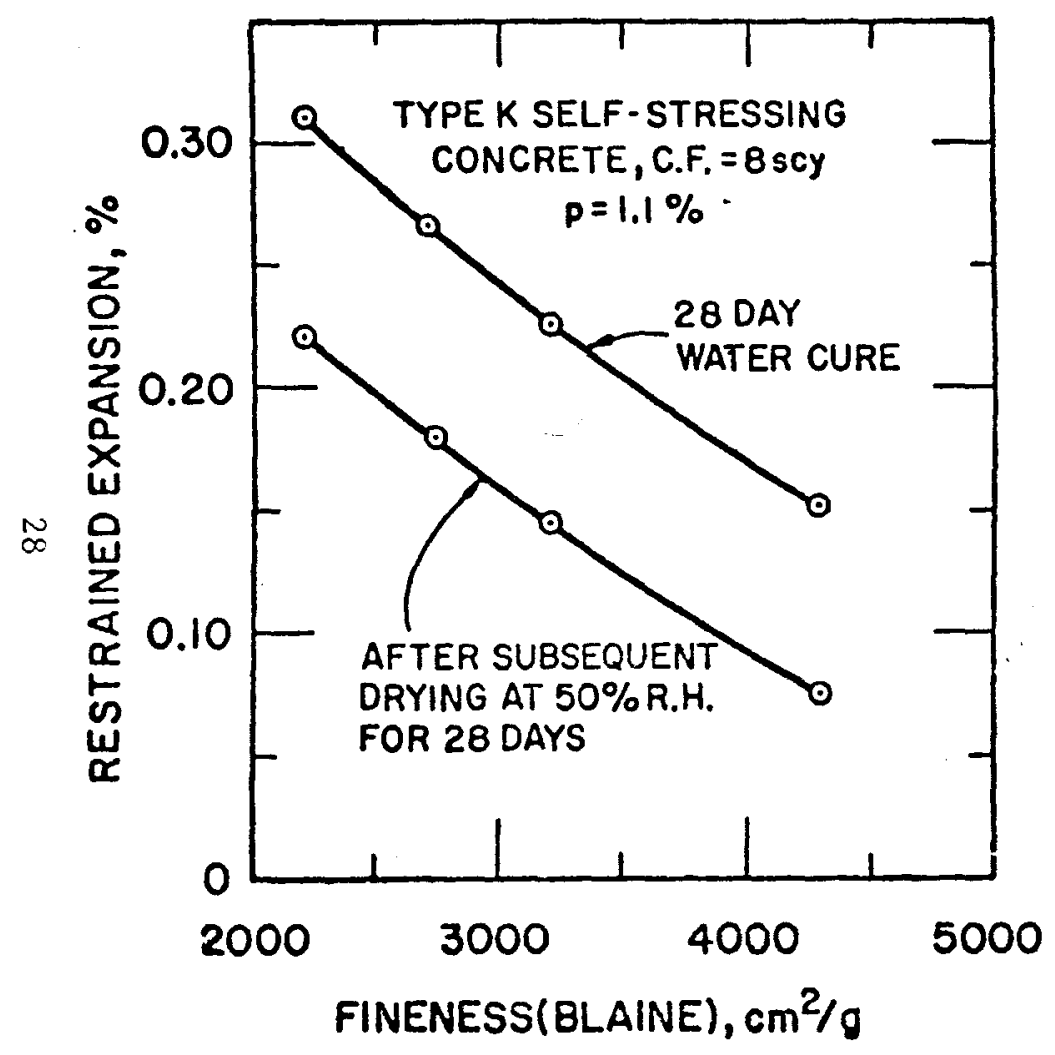

FIGURE 3. EFFECT OF FINENESS OF TYPE $\because$ CEMENT ON EXPANSION OF CONCRETE

(University of California)

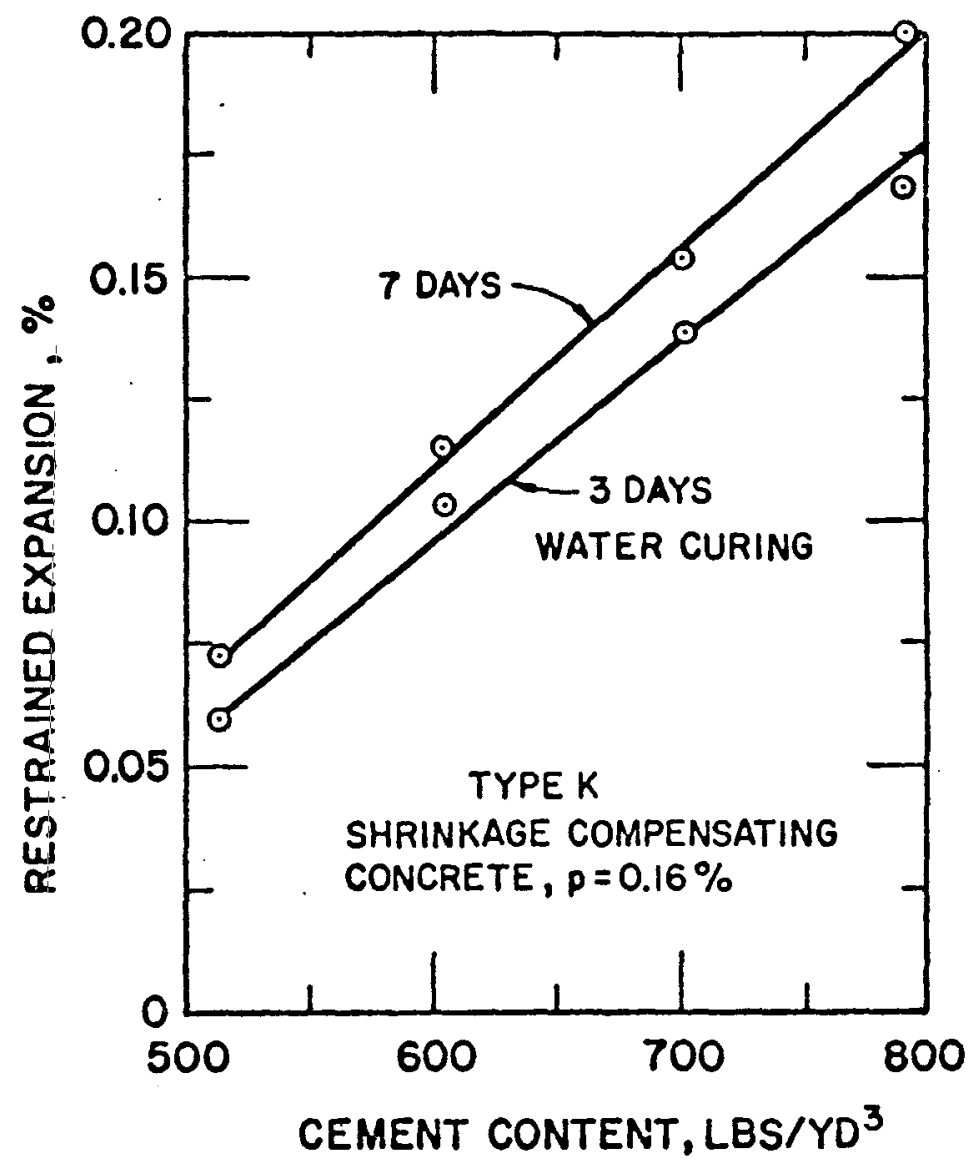

FIGURE 4. EFFECT OF CEMENT CONTENT ON EXPANSION (Kaiser Cement and Gypsum Corp.) 


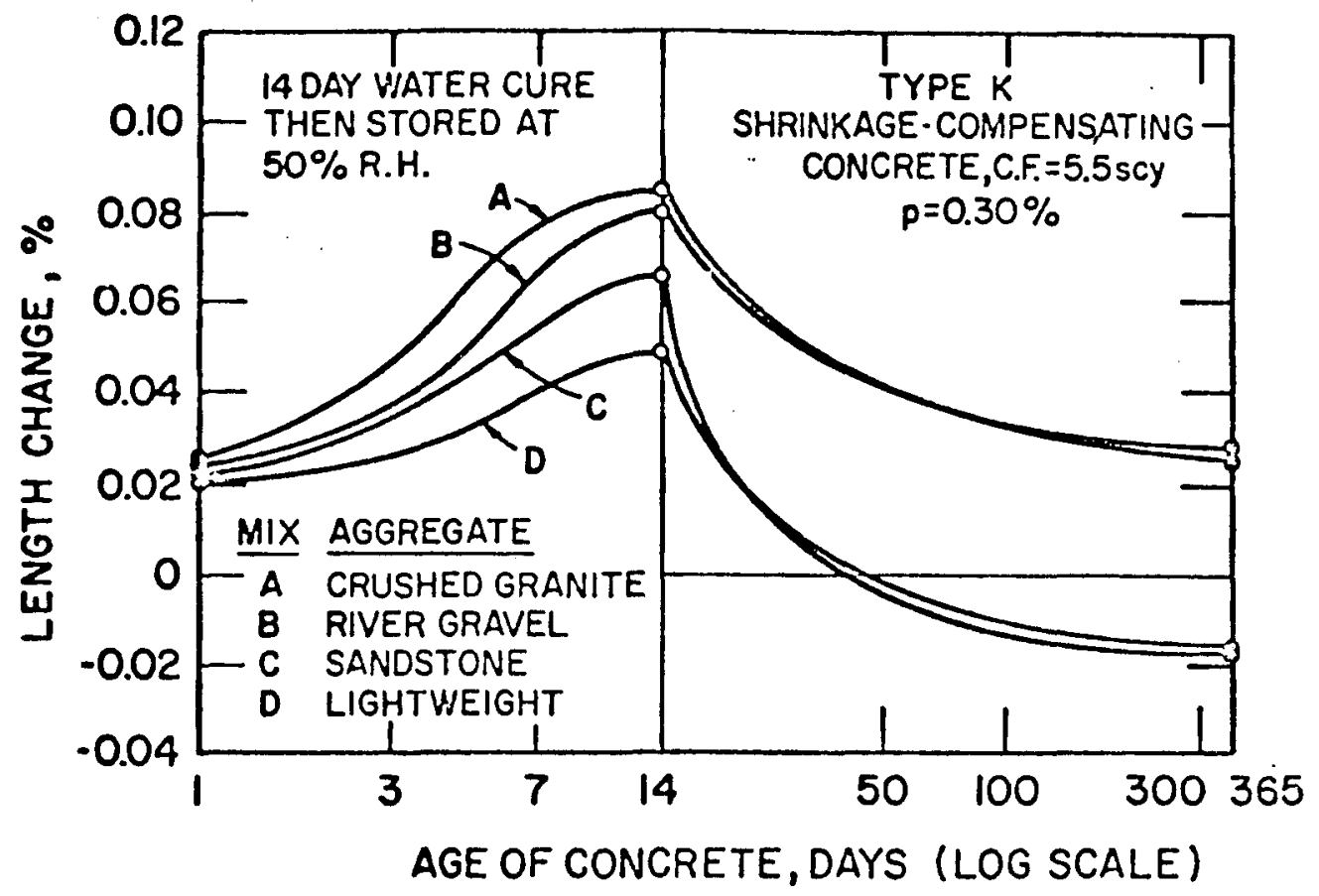

FIGURE 5. EFFECT OF AGGREGATE TYPE ON LENGTH CHANGE OF SHRINKAGE-COMPENSATING CONCRETE

(University of California)

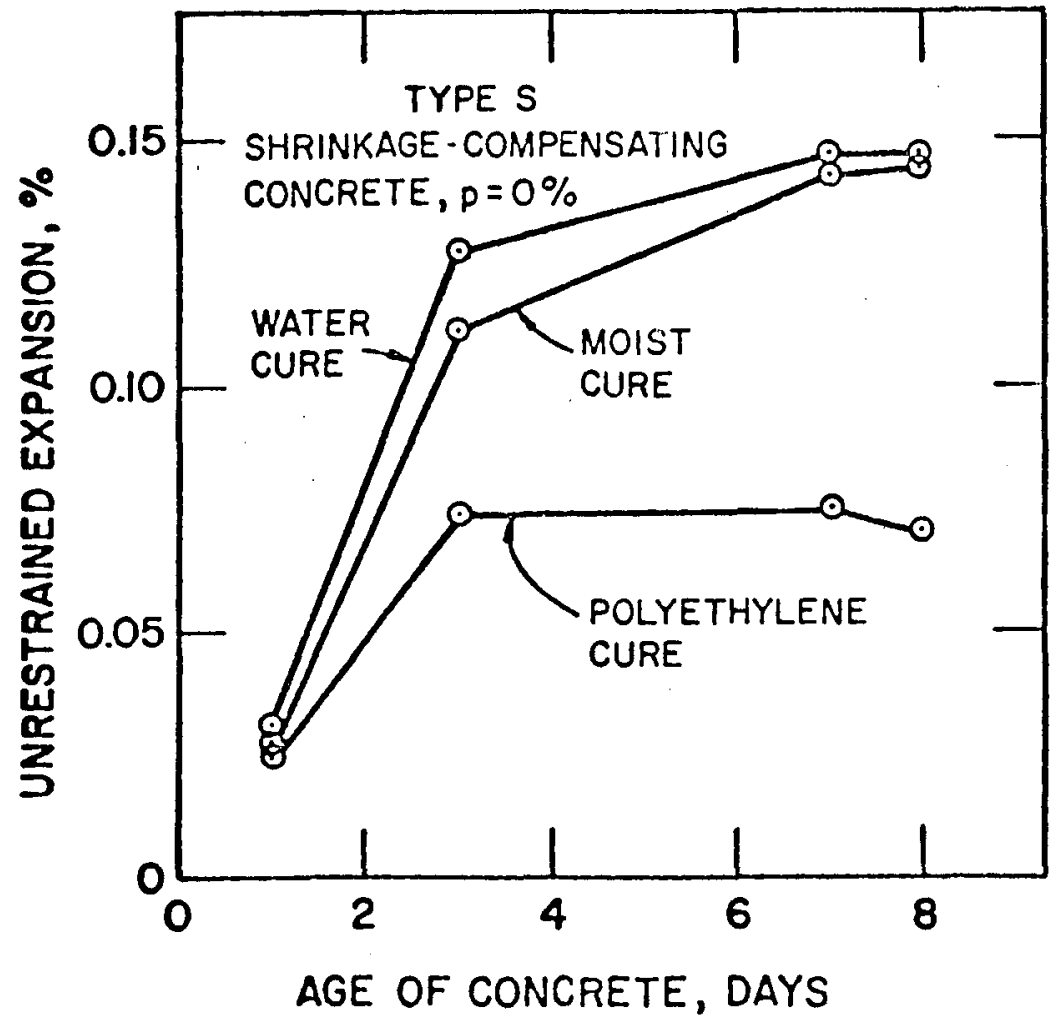

FIGURE 6. EFFECT OF CURING ON EXPANSION

(Portland Cement Association) 


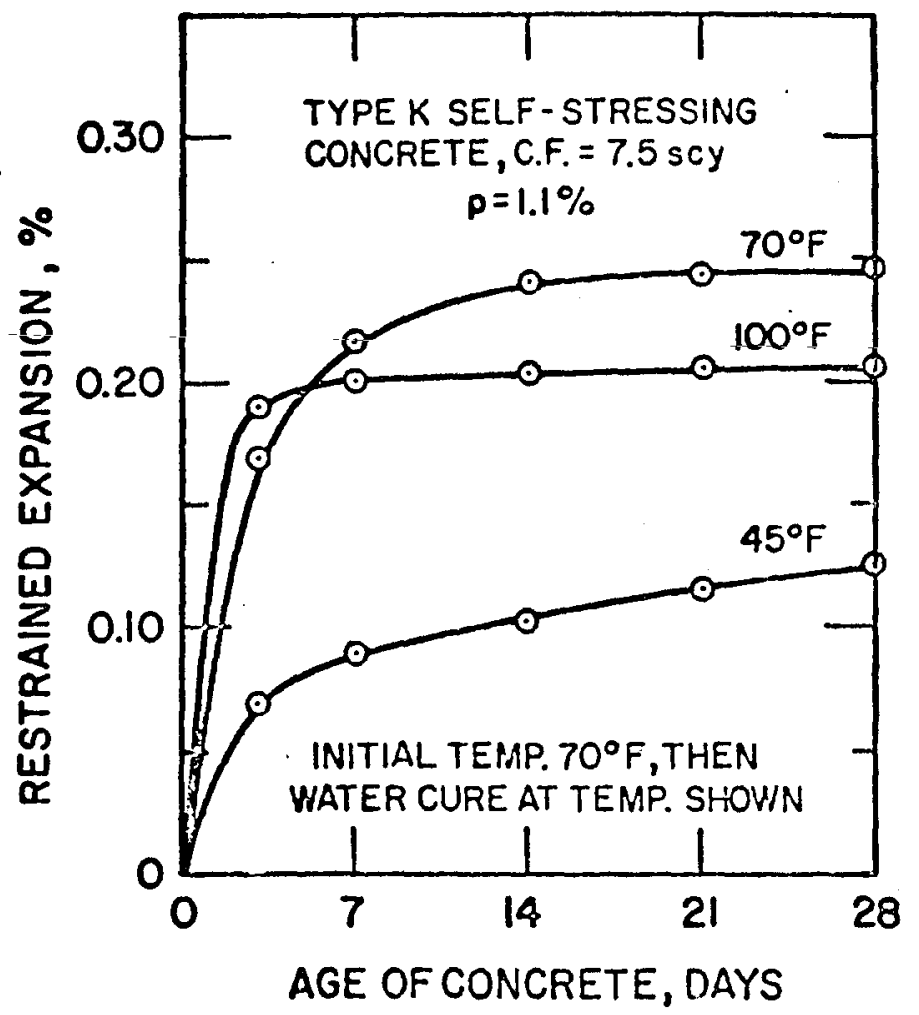

FIGURE 7. EFFECT OF CURING TEMPERATURE ON EXPANSION OF CONCRETE

(University of California) 


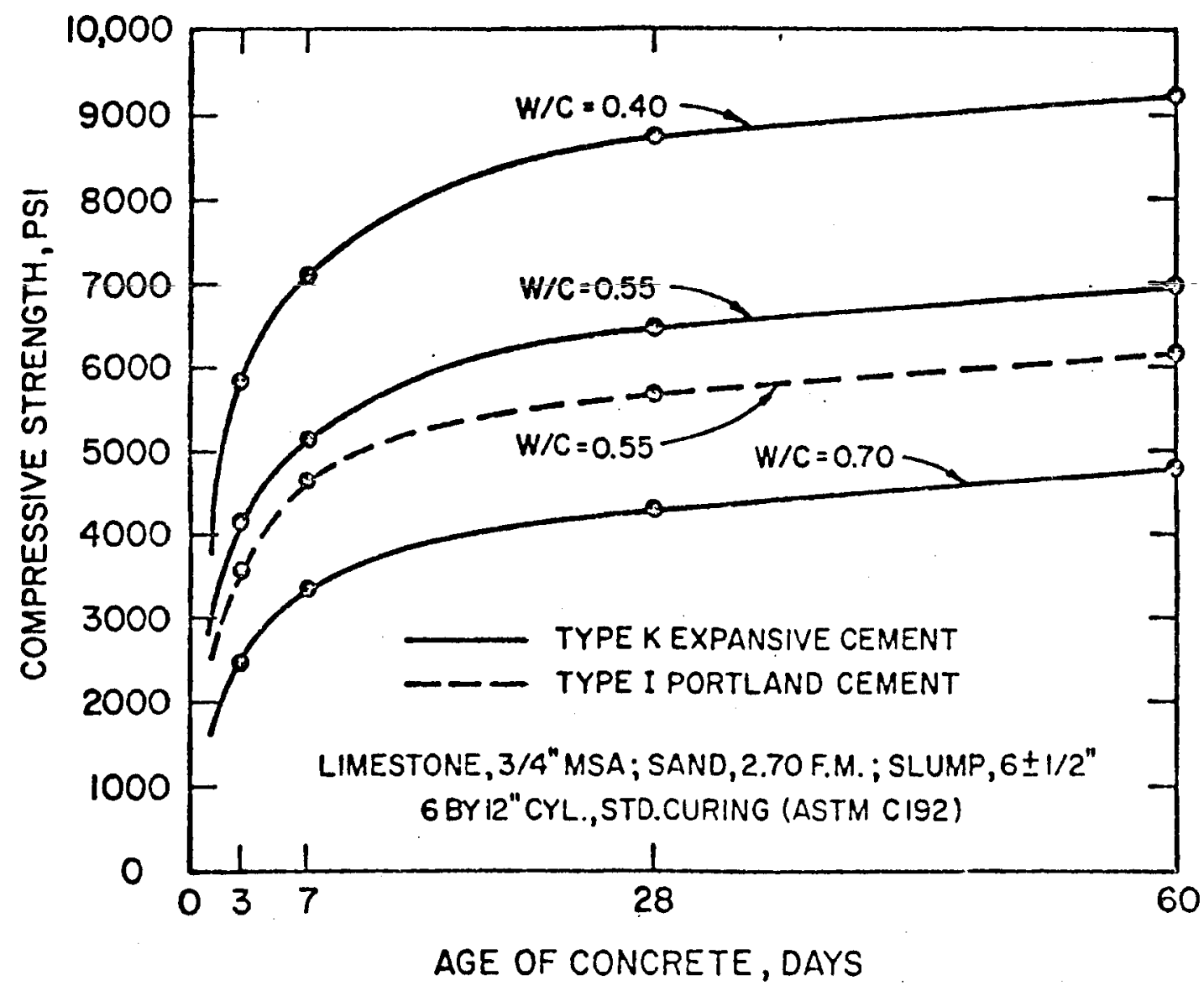

FIGURE 8. COMPRESSIVE STRENGTH OF SHRINKAGE-COMPENSATING CONCRETE (Texas Industries, Inc.) 


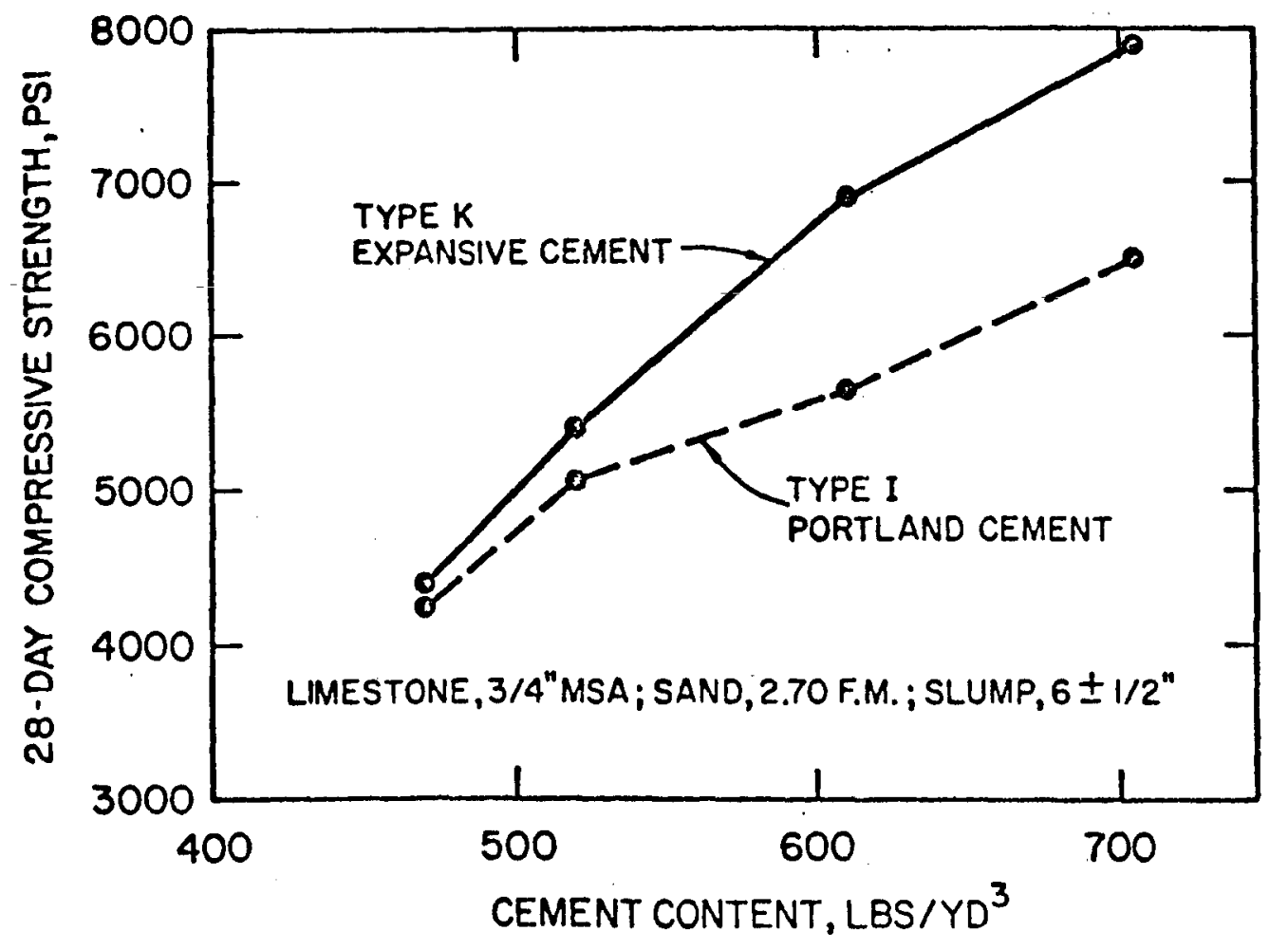

FIGURE 9. EFFECT OF CEMENT CONTENT ON 28-DAY COMPRESSIVE STRENGTH OF SHRINKAGE-OOMPENSATING CONCRETE

(Texas Industries, Inc.) 


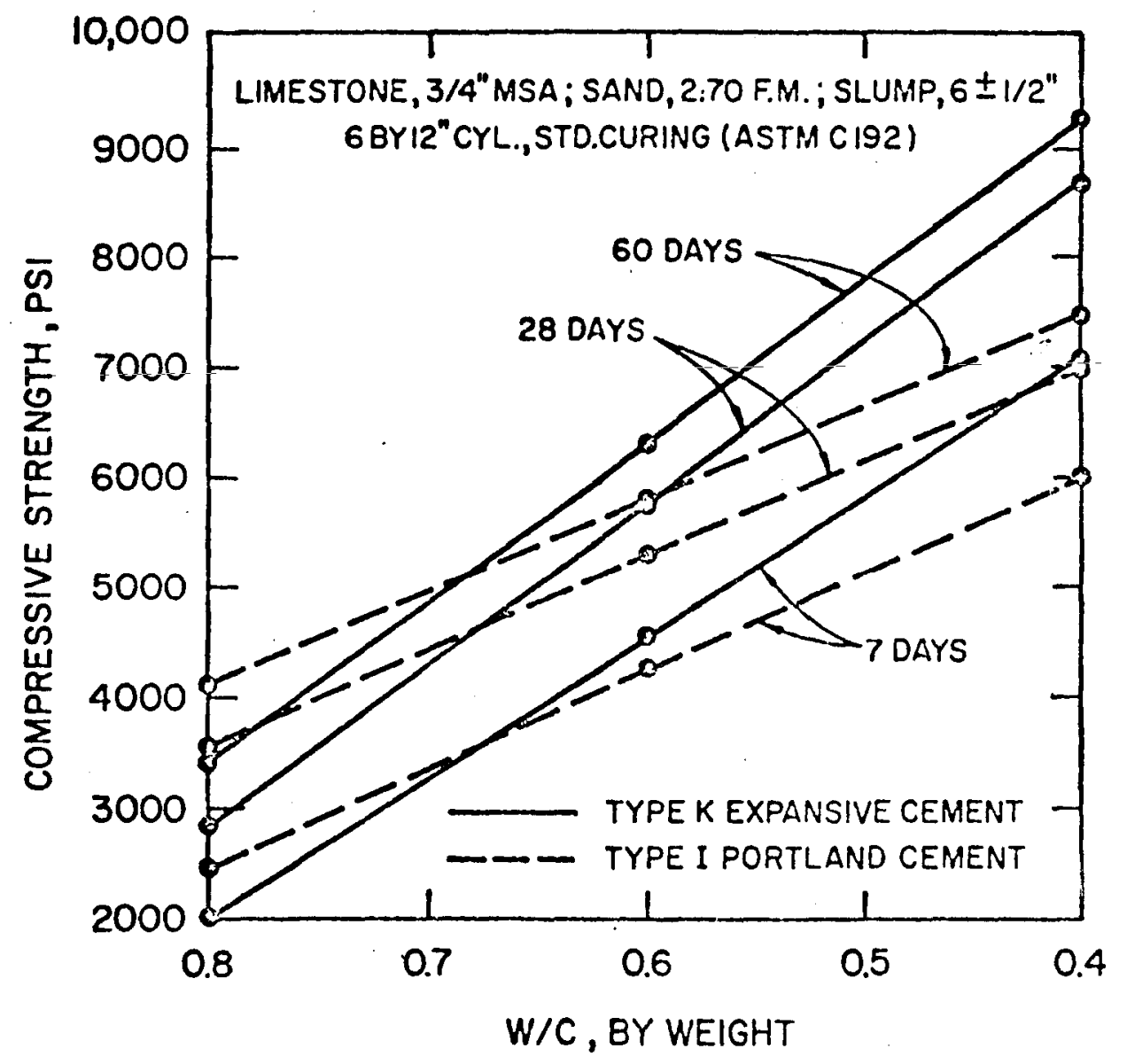

FIGURE 10. EFFECT OF W/C ON COMPRESSIVE STRENGTH UF SHRINKAGE-COMPENSATING CONCRETE

(Texas Industries, Inc.) 


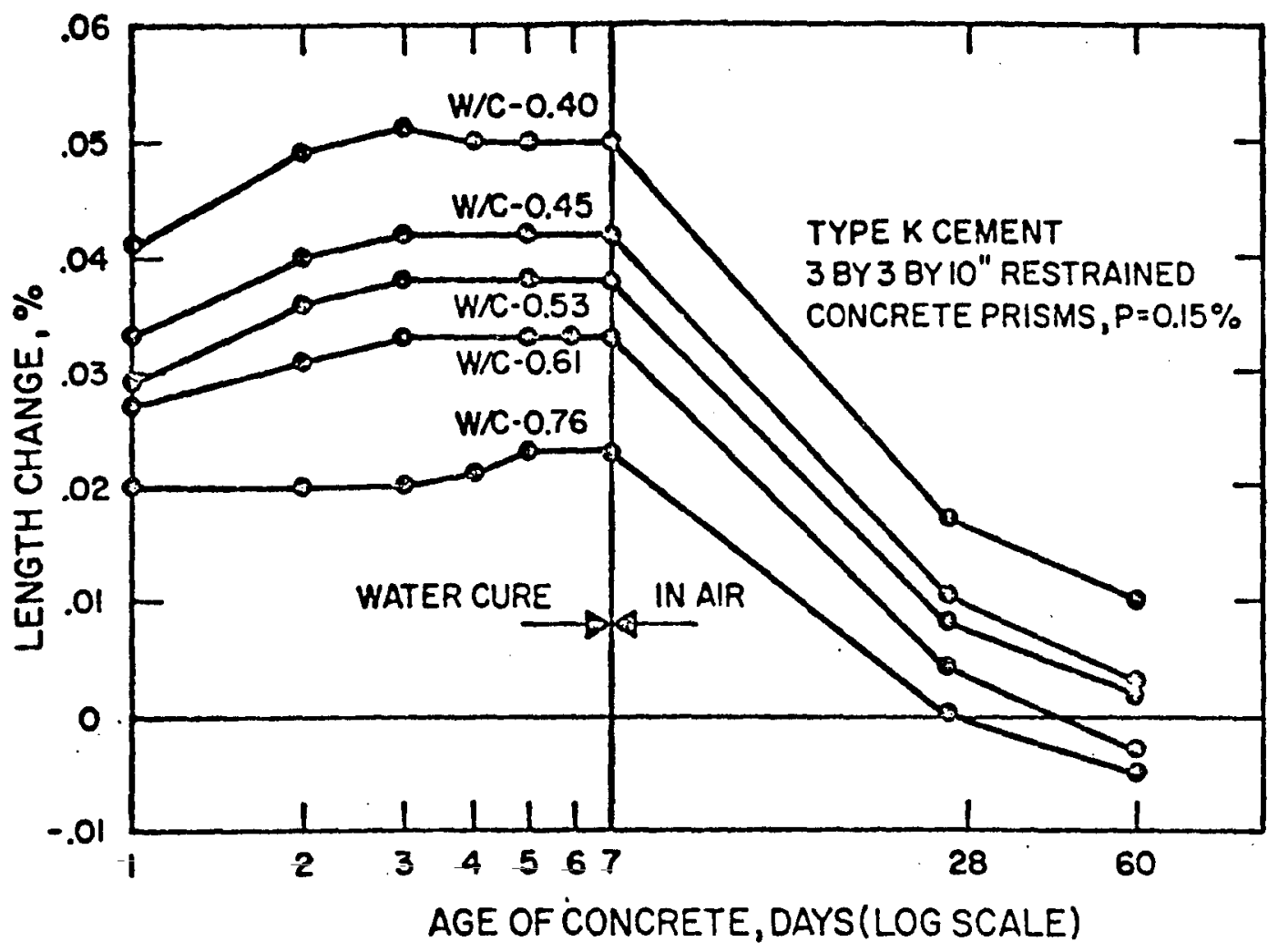

FIGURE 11. EFFECT OF W/C ON LENGTH CHANGE OF SHRINKAGE-COMPENSATING CONCRETE (Texas Industries, Inc.)

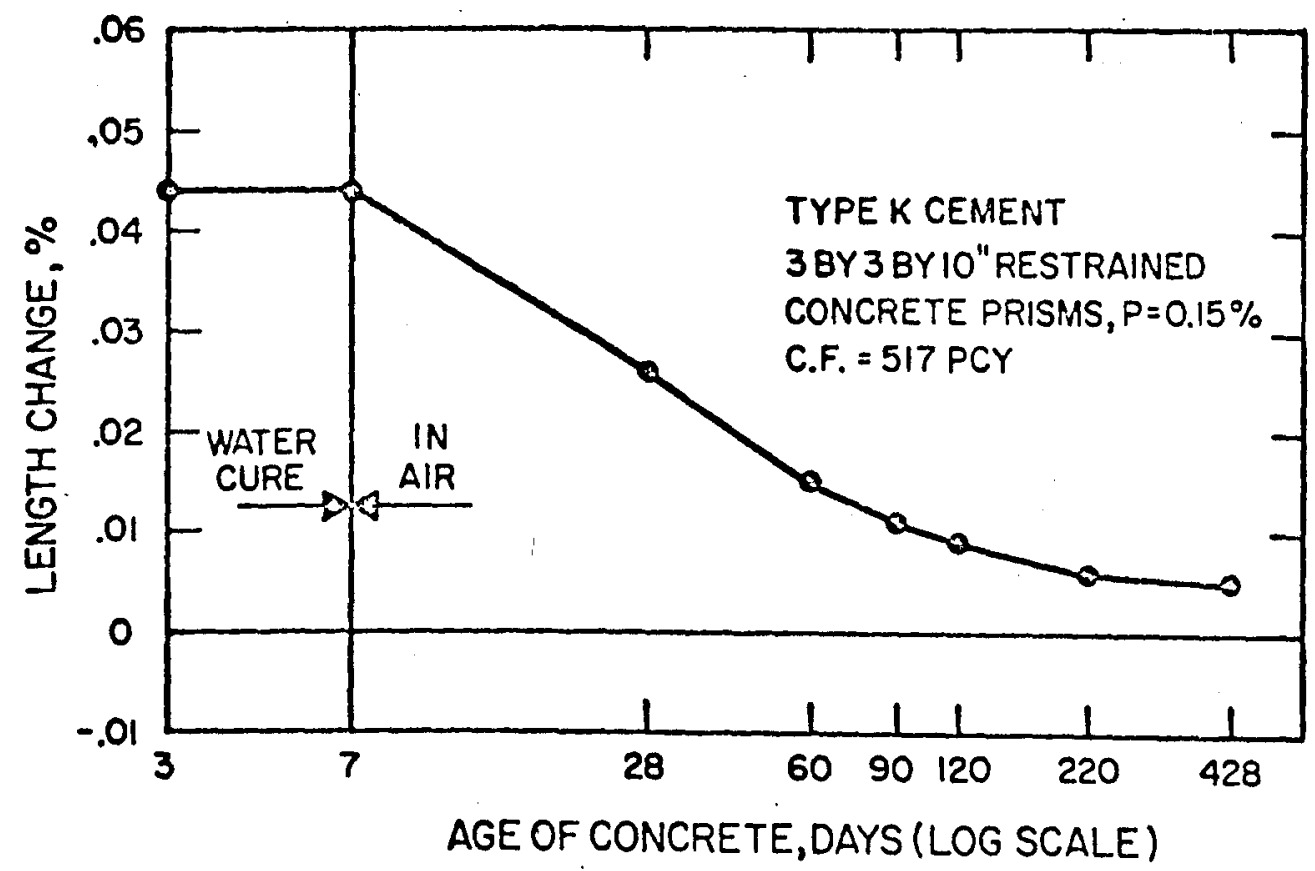

FIGURE 12. LENGTH CHANGE OF SHRINKAGE-COMPENSATING CONCRETE DURING 14 MONTHS OF DRYING

(Texas Industries, Inc.) 


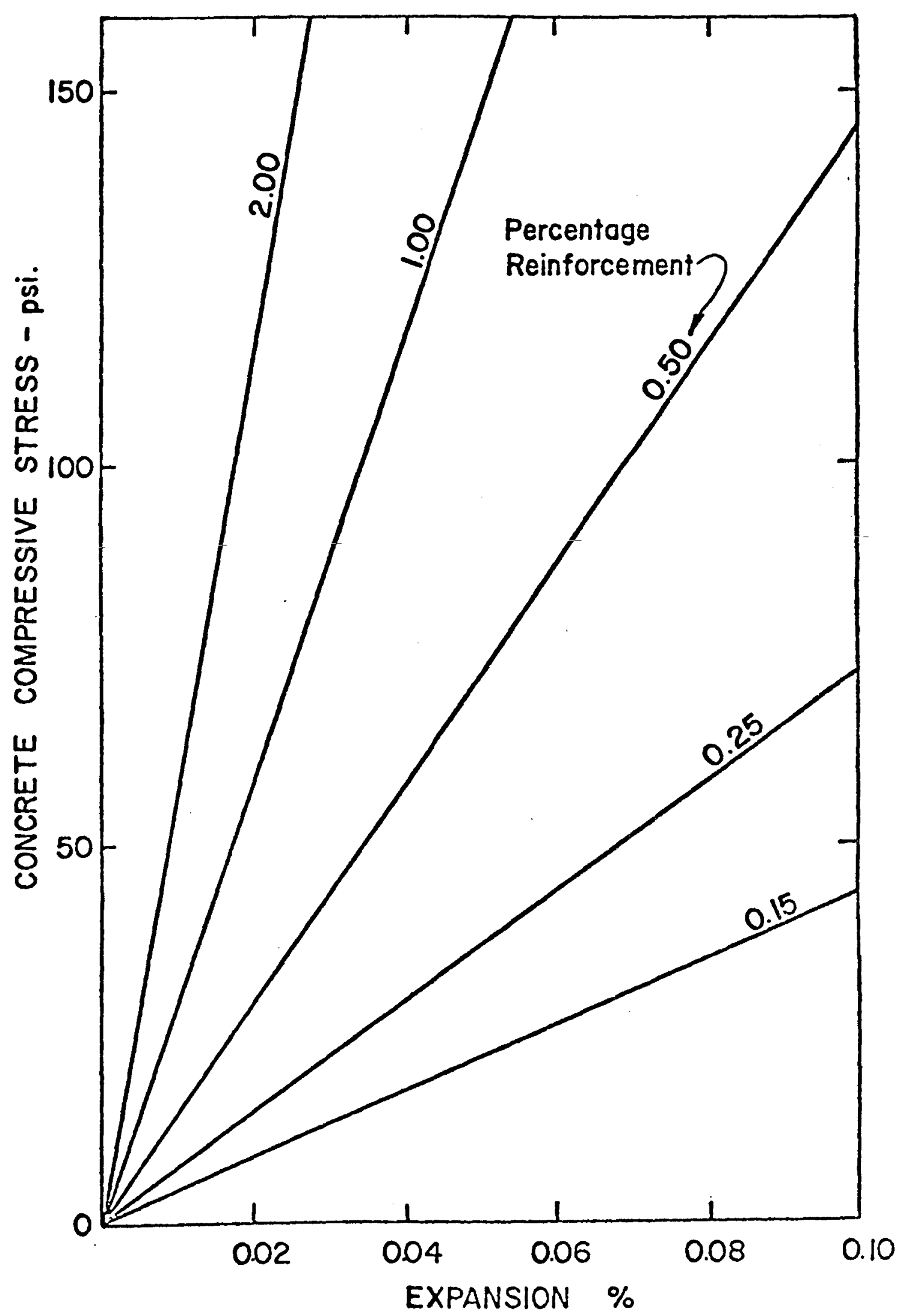

FIGURE 13. COMPRESSIVE STRESSES INDUCED BY EXPANSION 
DOCUMENT CONTROL DATA - R \& D

(Security clessification of thlle, body of abstrect and indexind snnotellon must be entered when the overell report ie clesellled) ORIGINATING ACTIVITY (Coporale author)

U. S. Army Englneer Waterways Experiment Station

Vicksburg, Mississippi

20. REPORT ECURITY CLABSIFICATION

Unclassifled

REPORT TITLE

EXPANS IVE CEMENTS AND THEIR USE

4. OESCRIPTIVE NOTES (TYPe of report end Incluelve dafes)

Final report

5. AU THOR(S) (Fliat nage, Elddlo Inllial, last name)

George C. Hoff

\begin{tabular}{|c|c|c|}
\hline $\begin{array}{l}\text { 6. PEPOAT OATE } \\
\text { Oetober } 1972\end{array}$ & $\begin{array}{l}\text { 7. TOTAL NO. OFPAGES } \\
40\end{array}$ & $\begin{array}{c}\text { 7b. NO. OF REFS } \\
6\end{array}$ \\
\hline $\begin{array}{l}\text { D. CONTHACT OR GRANT NO. } \\
\text { b. PROJECT NO. }\end{array}$ & $\begin{array}{l}\text { 9. ORIGINATOR'S REPORT } \\
\text { Miscellaneous Paper }\end{array}$ & $\begin{array}{l}\text { BER(\$) } \\
2-22\end{array}$ \\
\hline c. & $\begin{array}{l}\text { Ob. OTHER REPOAT NO(S) } \\
\text { (MTS roport) } \\
\text { CTIAC IIO. } 8\end{array}$ & ther numbert that may be eeclened \\
\hline
\end{tabular}

10. DISTRIQUTION ITATEMENT

Approved for public release; distribution unlimited.

\begin{tabular}{|l|l|}
\hline 11. SUPPLEMENTARY NOTES & 12. SPONSORING MILITARY ACTIVITY
\end{tabular}

13. ABSTACT The primary purpose of expansive cement concrete is to minimize cracking in concrete paventents and structures caused by drying shrinkage. Various types of expansive cements and their ploperties ine reviewed. The expansive mechanism and factors affecting it are also reviewed. The physical propurtier of o: pansive concrete alon with practical considerations such as mixing, placing, finishint, and curing are discussed. Structural design criteria for these concretes are reviewed. Applications are suggested. Expansive cement types $\mathrm{K}$, $\mathrm{M}$, and $\mathrm{S}$ are available in shrinkage-compensating and self-stressing brades. The ancunt of expansive potential a cement has determines its grading and is controlled by the in redients and formulation of the cement. The effective utilization of this potential is controlled by the cement supplitir or user or both. Cement content, aggregate type, mixing times, curing, temperature, and restraint can affect expansici. Expandive cement is effective only when the hardened paste made with the cement is sufficiently restrailed from expandin so that compressive stresses are developed in the material. Seven-day restralned prism expansions for concrete made with shrinkage-compensating cement are usually within the limits of $0.03 \%$ to $0.10 \%$. This corresponds to compressive prestress developments in the concrete in the range of 25 to ion pis ( 0.17 to 0.69 merapascals). The proportioning and properties of concrete made with shrinkage-conrensating expansive cement are generaliy similar to those of corresponding portland cement concretes mals witl: type I and I.I cements. Additional batching water may be required with types $K$ and $s$ cement to nchieve tice neceisary workability. Increases in water-cement ratio of 0.05 to 0.10 over that of comparably designed portland cement concrete are common. The additional water does not affect the strength. Most air-entraining, waterreducing, and water-reducing-retarding admixtures can be used with expansive caments, but their compatihility chould be checked. No special placing equipment and techniques are needed for expansive cement concruten. Water curing is an absolute necessity. Finishing may require greater manpower for shorter periods of tis. than for normal concrete finishing operations. The most reliable and controllable restraint for expensivecement concrete is provided by conventional reinforcing steel. In most instances, ronload bearin: members and slabs on grade should contain a minimum of $0.15 \%$ reinforcement. Using expansive cement concretes, slab placement areas can be increased approximately 10 times over those presently obtained with conventional concrete, thus eliminating many constmaction joints. Maximum contraction joint spacings of up to 150 ft ( 45.7 meters) are possible. Shrinkage-compensating concretes have been used in most situations where portland cement concretes have been used (i.e., in parking facilities, tilt-up construction, pavements, water and waste-water works, swimming pools, sports arenas, tennis courts, transportation centers, warehouses, architectural applications, and precast operations). 


$$
[\mathbb{L}
$$

